УДК 327(48-04:470):[352:351.88](091)

\title{
CONFLICT AND COOPERATION IN PUBLIC SPACE. SYMBOLIC (RE)NEGOTIATION OF HISTORIC AND CONTEMPORARY SCANDINAVIAN-RUSSIAN BORDER ${ }^{1}$
}

\author{
Heino Nyyssönen \\ University of Tampere, \\ vul. Kalevantie 4, Tampere, Finland, 33100, tel. (+358 3) 355 111, \\ e-mail: nyyssonen.heino@gmail.com \\ Jarosław Jańczak \\ Adam Mickiewicz University, \\ 89a, Umultowska Str., Poznań, Poland, 61-614, tel. (+48 061) 8296625 / European \\ University Viadrina, Große Scharrnstrasse 5, 15230 Frankfurt an der Oder, Germany, \\ tel.(+49 335) 5534 2581, e-mail: jaroslaw.janczak@amu.edu.pl
}

\begin{abstract}
Border twin towns are locations of particular symbolic importance for governing projects aimed at the creation of national and international spaces. Local and central authorities have utilised public monuments and other symbols there as a way of «inventing tradition» [15], and narrating about conflict, cooperation and even collaboration legacies. The metaphor of «integration laboratories» [13] makes them perfect places for border (re)negotiation [5]. Referring also to Reinhart Koselleck's [27] ideas concerning war memorials we argue that monuments represent symbols exhibited in public space: they have a specific function, in hinting something, «which does not exist as a thing or matter immediately perceptible to the senses» [38, p.40]. Moreover, a symbol «tells about some other reality and is the crystallization of a linguistic description» [38, p. 40]. In this way, «materially existing objects are often useful in embodying and presenting abstract ideas, such as unfriendly relations, international socialism or EU integration, as well as strengthening a populace in their convictions toward these ideas» [5, p. 204]. The aim of this paper is to investigate historiographicallypublic space symbolism i.e. monuments, cultural memory and politics in three border twin towns (Narva-Ivangorod, Imatra-Svetogorsk and KirkenesNickel). It will, however, concentrate on the western part of the border. On the basis of these representations the paper aims to discuss broader foreign policy orientations, and in particular those after WWII: being the sites of intensive interactions they reveal a historic legacy of conflict between «Scandinavian space» and Russia. Further, they have recently employed (accordingly) three variants of historic-political (re)interpretations: new economic neighbourhood relations, EU common border and conflictive revival of Swedish historic legacy.
\end{abstract}

Key words: European-Russian border; bordering; de-bordering; border symbols.

\footnotetext{
${ }^{1}$ The French version of this article was published as: Heino Nyyssönen, Jarosław Jańczak, 2015, 'Conflit et coopérationdansl'espace public. (Re)négociationsymbolique de la frontièrehistorique et contemporaineentre la Scandinavie et la Russie', Revued'histoirenordique, (2015), No. 19. - P. 151-177.
}

(C) Nyyssönen Heino, Jańczak Jarosław, 2016 
Heino Nyyssönen, Jarosław Jańczak

ISSN 2078-4333. Вісник Львівського університету. Серія міжнародні відносини. 2016. Випуск 38

\section{Introduction}

The aim of this paper is to investigate the langue of borders on the ScandinavianRussian boundary by testing public space symbolism i.e. monuments, cultural memory and politics in three border twin towns (Narva-Ivangorod, Estonian-Russian; ImatraSvetogorsk, Finnish-Russian; and Kirkenes-Nickel, Norwegian-Russian), with a special focus on the western part of the border. On the basis of these representations the paper aims to discuss broader foreign policy orientations, and in particular those after the Second World War. Being places of intensive interactions they reveal a historic legacy of conflict between «Scandinavian space» and Russian space that recently have employed (accordingly) three variants of historic-political (re)interpretations: conflictive revival of Swedish historic legacy, EU common border and new economic neighbourhood relations.

Symbols and symbolic policies matter on the Scandinavian - Russian border. Probably the most well-known example is related to the case of Karelia: this case of monument politics deals with the fate of the Finnish Lion figure and Peter the Great in Vyborg (Viipuri, Viborg, Wiborg/Wiburg). Located in Karelia, a borderland between East and West, this medieval city belonged to Sweden from the fourteenth century, then to Russia and since 1917 to independent Finland. Thus, next to the $10^{\text {th }}$ anniversary of independence in 1927 a new monument, the Finnish Lion, was established on Tervaniemi Hill in the city, opposite to Vyborg Castle. At the same time another statue, Peter the Great, who had conquered the city in 1710, was removed from the site. Modelled after the Finnish coat of arms, and protecting Karelia with a paw, the lion symbolised strong nationalist sentiment. The lion looked to the East until the end of the Winter War and Moscow Peace Treaty, when Viborg remained in the Soviet hands. They restored Peter the Great and the former state of things. When Finns conquered Viborg in 1941, they restored the lion again. However, as Finns lost Karelia for the second time in 1944, Peter the Great won the competition and superseded the lion yet again. The lion was lost for decades, and although badly wounded and battered, it is nowadays located in Monrepos Park next to the city [52]. Peter's position is even more central nowadays: hewelcomes all entering the city next to the Castle.

The Vyborg example might be an extreme case in the Nordic countries, but at the same time it reveals questions of public space symbolism and the role of monuments role in them. It also forces to ask if similar developments can be observed on other parts of the Scandinavian-Russian border and if the peculiarity of specific «borders» is differently manifested in symbolism and symbolic policies. On the one hand, commemoration is a very human, natural act that even overcomes grief and mourning. However, on the other hand, statues of rulers and state actors are strong symbols of cultural memory, which mark and conquer public space, demonstrate power and can easily lead to bitter, even ridiculous political campaigning and wrestling over «our space» $[3 ; 29 ; 36]$. But do they finally matter that much? After all, surely statues are only part of history that do not have any particular strong identification among people? Here, our task is to study their significance on twin cities next to three borders in Northern Europe. Do statues and monuments separate or unify people in twin 
cities? Are they and their (changing) interpretations locally or centrally inspired? And finally, what do they say about the homogeneity of «Scandinavian space» when confronted with Russia?

In order to answer these questions the authors decided to test public space symbolism that is reflected in monuments in twin towns. They are considered to be the «laboratories» of interstate reactions and European integration. Three of these towns were selected, representing three historical sections of the Scandinavian-Russian border and located on contemporary Estonian-Russian, Finnish-Russian and Norwegian-Russian boundaries. Comparative analyses settled into a framework of the concept of invented traditions allowed the author to build the model of border symbolisation on the investigated boundaries. The methods applied include also visual analyses of the tested objects, primary and secondary literature as well as historical interpretation.

\section{Borders, border studies and the Scandinavian-Russian border}

The constantly growing academic interest in borders has resulted in an eruption of border studies in the last two decades. Both processes seem to concentrate, on the one hand, on determining the research agenda of border studies. On the other, these concentrate on understanding and translating the nature of borders as well as processes affecting them or occurring on them.

In regard to the thematic focus of border studies, they subsequently concentrated on geopolitical research, the spatial-economic dimension of borders [4], security considerations [44], conflicts spaces [33] and finally on them as institutions [35] as well as social and discursive constructs [42]. Phantom borders - ones that no longer exist but that still influence current processes - were also investigated [39]. Border studies have been marked by a conceptual change in recent years though, that has seen «shifts from largely functional to cognitive and symbolic perspectives on border (...), accordingly, borders themselves can be seen as products of a social and political negotiation of space; they frame social and political action and are constructed through discursive practices at different levels and by different actors» [42]. Bordering is a key concept in this approach, being «a multilevel process that takes place, for example, at the level of high politics, manifested by physical borders and visa regimes, as well as in media debates over national identity and migration (...), everyday border-crossing experience and issues of family, gender, sexuality and cultural and personal understandings of borders» [42]. Consequently, «borders can be conceived as a bridge to understanding social, political and spatial change» [42].

Classical, but still actual (especially in the context of the very recent revival of traditional and almost forgotten understating of borders), forms of borders are frontiers and boundaries. The former reflects the empirical reality of openness and overlapping influences of various centres [53, p. 687-688] (as being zones «of contact between two entities or social systems» [12, p. 185], or even an «area which was part of the whole, specifically that part which was ahead of the hinterland» [28, p. 269-270]. Territorialisation of states together with Westphalian political order in Europe resulted in a shift in the dominating form of borders towards being boundaries, which are «more or less strict territorial limits» [12; 35] that precisely demarcate state 
sovereignty $[37$, p. 8$]$ as well as power structures $[8 ; 19 ; 53]$. Internally, this process results in homogenisation and unification of various political, economic and cultural structures within those precisely marked lines, often in opposition to how those fields are organised on the other side of the border.

Political changes in Europe in the last decade of the twentieth century resulted in there vival of both concepts in Europe, both academically and empirically. On the one hand, European integration processes almost erased boundaries, replacing them with frontiers inside the Schengen zone and reinvented them on the external Schengen borders. On the other hand, the disintegration of the Soviet Union resulted in boundarisation of previously non-bordered spaces, together with the (re)appearance of a set of new states in this part of the continent. In this context, the border between Scandinavia and Russia experienced both of the signalized processes, making it especially interesting from the point of view of the present research. To continue, however, a brief debate on understanding «Scandinavian space» and Russian space seems necessary.

This article's understanding of Russia is based on both the historical continuity of the Russian state and its imperial nature. Consequently, the authors consider the states of Ivan the Great, and then Peter the Great, the Soviet Russia and the Russian Federation as various manifestations of a very similar spatial-political concept that neighbour, on its North Eastern outskirts, the «Scandinavian space».

The «Scandinavian space» is used here as an equivalent to Scandinavia, especially in its historical meaning, and is related to the medieval Swedish and Danish presence on the outskirts of the region, especially in contemporary Finland and Estonia. As a concept, Scandinavia has had many meanings, and they can be found in everything from geography to identity politics. There, the most contested topic is whether Finland, whose linguistic background differs from the others, can be counted as part of this group; between the World Wars, Finland was sometimes counted even as the fourth Baltic State. Nowadays, this flexibility has given room for Estonia's political identification with the North as well. Thus, in the strictest geographical sense, Scandinavia is a peninsula, which includes North-West Finland, too. However, in a broader sense, Scandinavia refers to all Nordic countries and their cooperation, and Finland no doubt belongs to this club.

The British geographer W. R. Mead noticed that Finland's borders have changed in the course of history more often than those of any other European country [54, p. 41]. This is particularly true in regard to its Eastern border, at a time the SwedishRussian border, which since the fourteenth century shifted towards the East before shifting to the West from the eighteenth century and Peter the Great. Moreover, Finns have referred to cultural arguments, bedrock and coined the concept Fennoscandia, which on the one hand aimed to secure Finns Scandinavian, Western orientation, but, on the other hand, potentially legitimised Karelia for Finland, as the concept included Karelia and the Kola Peninsula under its umbrella.As Mari Vares noticed, the geological concept of Fennoskandia was used to define natural Finland as oppositional to political borders [54, p. 53]. 
In Norway and Estonia, the border with Russia is essentially shorter. In the North, a periphery area of the Saami people and reindeer husbandry, was under Sweden's (i.e. Norway's) and Russia's joint governance until 1826, when it was divided between Russia and Norway. In the Baltic, the Scandinavian influence was relativelystable on the Narva-Peipus line but varied more towards Poland-Lithuania. There, it reached the present Riga and the Daugava River (in Latvian, in Swedish), known asthe Western Dvina or even Väinäjoki in Finnish - all these becoming part of Russia under Peter the Great until 1721.

Consequently, three already enumerated state boundaries are to represent the legacy of border between «Scandinavian space» and Russia.

\section{Twin cities as laboratories of macro-processes}

The authors decided to examine twin cities located on the Scandinavian-Russian border. Despite various names describing this category in academic literature [20, p. 5; 10 , p. 15-17; 18, p. 27], they will be understood in this article following Helga Schulz, Katarzyna Stokłosa and Dagmara Jajeśniak-Quast as «towns separated by an international state border» [41, p. 3], supplemented by shared feeling of togetherness [11, p. 1], regardless as to whether they are in a cooperative or confrontational mode. Here - contrary to the category of border twin towns [18] - the distance between the cities is less important than the interactions between them. Even if they are not located directly on the border but are mutually oriented, they belong to the category. Being mutually crucial points of reference they cross state boundaries in order to improve their own position (for example by gaining access to resources unavailable on their own side of the border) or they serve as interpreters of the state's intentions (by reflecting the centre's policies, positions, intentions, etc.).

Twin cities can have three types of origins and appear as a result of the division of previously non-border related settlement (divided), constructed on one of the border sides in answer to the town located on the other (duplicated), or are created of an infrastructure linking previously isolated settlements (connected) [10].

Twin cities have been considered anomalies [30, p. 1], especially in the boundarised Westphalian spatial-political order of Europe. Security considerations led to the creation of territorial structures where the centres constituted concentrated areas of resources. Peripheries, especially border areas, permanently exposed to external threat, served as outposts and external limits of state sovereignty. Being interfaces of power, they were used not only for the physical expression of respective states' structures (border fortresses, customs stations, etc.) but also for the symbolic manifestation of statehood, the power of national centres, and revealed in this way the actual character of interstate relations (conflict, cooperation, friendship, etc.). They say a lot about the ongoing boundarisation or frontierisation processes happening on given borders.

Twin cities served perfectly those purposes, sometimes being (instrumentally) used by their national centres, sometimes taking the initiative on their own and using advantageous circumstances for their own aims by employing a strategy of paradiplomacy. In both cases a metaphor of «laboratory» is applied to the couples. It employs a concept of scale change [23], where reduced proportions can better serve 
both observation and the understanding of the investigated phenomenon. In a laboratory, phenomena and processes are tested under controlled circumstances [13], in down-scaled optics and with much better observation possibilities. Laboratories, by analysing samples, can say a lot about the "real" reality. And this is exactly what twin cities can serve for when investigating relations between states, nations, cultures, historical memories, competing political narratives, etc. In the academic literature there are consequently «cultural laboratories» [46, p. 146], «laboratories of intercultural relations, even multiculturalism, because they are situated where people cross each other's paths» [41, p. 8], «laboratories of differentiated integration» [13], or laboratories of «governance capacities in their cross-border form» [18, p. 90].

In this article, twin cities will be used as laboratories of Scandinavian-Russian interactions, places where they - regardless of whether they are top-down (centrally) or bottom-up (locally) inspired. There are locations «of particular symbolic importance for the legitimation of governing projects aimed at the creation of new national and international spaces» [5]. They legitimise power or consolidate it, especially there where conflictive territorial legacy has been the case [4].

\section{Public space symbolism - the language of monuments}

Andrew Asher and Jarosław Jańczak propose in their studies on the symbolic discourses of borders a concept of inventing traditions through public symbols [5]. They use the concept of «invented traditions» by Hobsbawn and Ranger, who stress that «a rapid transformation (...) weakens or destroys the social patterns for which 'old' traditions had been designed» [15, p. 4-5], and leads to the growing tendency of the invention of new traditions. These new traditions are to serve three purposes: they are to (a) transfer new values, (b) legitimise relations of authority and institutions' status and, (c) generate feeling of belonging. Invented traditions are communicated by symbols. We argue that invented traditions are not necessarily artificial, even the commemoration of wars have a lot of variation. It is believed, following Benedict Anderson and his «imagined political community», that symbolic «commemoration of the past is central to (...) nation building, where in wherein newly created or radically reconfigured states seek to bolster their legitimacy and authority» [43, p. 281]. Symbols and symbolisation can be considered a means of communicating the newly invented traditions to the wider audience. But what are the symbols?

According to Ulf Hedetoft [14, p.7], «symbols and symbolization are key concepts for an understanding of what is going on in present-day Europe, with its complex and often confusing interaction between varying demarcations and definitions of Self as opposed to what is perceived and posited as Other at given moments and with changing configurations of identity, interests and political context». Following Pekonen's understanding of symbols, they hint «at something, which does not exist as a thing or matter immediately perceptible to the senses (...) tells about some other reality and is the crystallization of a linguistic description» [38, p. 40]. He pays attention however to the fact, that «... the power of symbols and symbolic power do not lie in symbols and symbolic systems as such; power is in hands of those social forces and groups who authorize these symbols, whose symbols they are, whose selfidentity is expressed in these symbols» [38, p. 41]. Consequently, symbols are key 
elements in determining «us» and «others», a physically embody abstract idea, and express power relations. Frank Ankersmit [2, p. 94-95] sees monuments as tools of «indexical function» - not telling about the past (as the historical texts does) but indicating specific directions of reflection. They become places of memory when being used as location of rituals and ritual socialization [1, p. 134]. They replace, at the same time, «communicative memory» with «cultural memory» [3] (unfortunately due to limitations of this text the authors decided not to explore systematically which social actors are the most crucial for perpetuating the memory of the historical events).

Public space monuments, even buildings, belong to cultural memory, and represent one of the ways of symbolisation of ideas, with regard to the three functions of «invented traditions». City twins, due to their role of laboratories, are locations where their message is especially loud and widely listened to. Even the way in which the border is marked, says a lot about relations of states neighbouring each other [50, p. 526]. Monuments are a step further - they additionally stress the message by attracting attention of publicity to specific ideas. However, the ideas expressed on borders originate often from the processes initiated and are inspired, or at least implemented, by the centres. As interstate contexts differ from case to case, also border relations are different on various borders. Consequently, various modes in regard to how the monuments talk on investigated borders can be expected, depending on local conditions. Kanerva and Palonen pay attention additionally to the dimensional flow of ideas, produced by centres and exported to peripheries. As the local conditions do not correspond with those on the edges, the original ideas can be either imitated (losing their original sense) or adapted (with a changing meaning that better fit local conditions) [24, p. 9]. On the other hand, there are studies proving that this onedimensional flow of ideas is not always the case. Ideas are sometimes peripherally inspired and only then penetrate the centres that incorporated them into the central agenda construction [17, p. 24].

Particularly memorials which commemorate violent death, provide a means of identification. Reinhart Koselleck [27] has studied war memorials, mainly in Germany and Europe, which he considered to be identity formations of survivors. On the one hand, they respect the ones killed, and on the other put surviving observers in a position where they are offered an identity. Particularly after the French Revolution, memorials dedicated to soldiers killed in action have steadily increased and moved from churches into open spaces and into the landscape: «It is not only the death of soldiers itself that serves political purposes, but the remembrance of it is also put to political service» [27, p. 291]. According to Koselleck, memorials are taken down if they are felt to be a threat. Memorials, however, like all works of art, have a surplus potential to take on a life of their own, or even to fall into oblivion. In this sense, monuments can also lose their immanent political function for future generations. For example, the French were able to afford to leave untouched the German war memorial of 1870-1871 in Alsace after 1918 - now a part of France. Koselleck noticed that even in the victor countries of 1918 the celebration of the armistice draws fewer and fewer people [27, p. 324]. 
Heino Nyyssönen, Jarosław Jańczak

ISSN 2078-4333. Вісник Львівського університету. Серія міжнародні відносини. 2016. Випуск 38

5. The cases

The above presented conceptual framework together with its operationalisation allows to compare already indicated cases of city twins. In the following sections the examples of Narva-Ivangorod, Imatra-Svetogorsk and Kirkenes-Nickel will be described, compared and interpreted. The focus is however mainly on the Western side of the border. This results from two factors. First, are the asymmetric relations within the investigated couples visible in stronger, bigger (as is the case in two of the three investigated couples) and sometimes even dominating towns located on the «Scandinavian» side. This is also visible in numerous monuments on the Scandinavian side in contrast to the situation on the Russian side where public space symbols are either missing or are of a marginal or irrelevant character. Second, it is the «Scandinavian space» that more intensively expresses its own position towards Russia in the tested couples.

\subsection{Narva-Ivangorod}

The pair of Narva and Ivangorod is at the main crossing point on the EstonianRussian border, on the way between Tallinn and Saint-Petersburg. The towns directly face one another over the Narva river and share a long history of togetherness.

The history of both tows is related to the Danes conquering current Estonian territory in the thirteenth century and building a castle on the left bank of Narva. The town grew around the castle and both were soon sold to the Livonian Order. The other riverbank was in 1492 taken by Ivan the Great and became a part of the Moscow Duchy. He constructed a second fortress, and soon a town named after the founder Ivangorod, which was a direct answer in opposition to Narva. This formed both a border post between Russia and the west as well as an object of a centuries long territorial competition - that can be to some extent compared to Vyborg. Sweden gained Narva in the second half of the sixteenth century and contributed to its economic development that is now visible in its dominating baroque style and the mythologised «golden age» of the town. Ivangorod was under Swedish control for the majority of the seventeenth century. In 1704, as the result of the Great Northern War, Narva became a Russian possession as a part of the Saint Petersburg province. This neighbourhood of the new Russian capital resulted in dynamic industrialisation of the town in the nineteenth century. Together with Estonian independence in 1918, both Narva and Ivangorod became as a single administrative unit a part of Estonia [31, p. 7] with the border located close by in the east. World War Two and the incorporation of Estonia into the Soviet Union resulted in administrative separation of both towns [20, p. 237] and divided them along the Narva river between the Estonian Socialist Republic from the Russian Socialist Federal Republic. The old town was almost entirely destroyed by the Red Army and the Estonian population - mainly evacuated before the front came [23, p. 545-546] - was replaced with Russian speakers [31, p. 122-132].

Estonia's independence in 1991 cut the functionally and culturally united towns with a new, guarded state border as well as border controls [40, p. 28]. The towns became an object of tensions between Estonia and Russia. Narva - the third biggest Estonian city with 65000 inhabitants - turned out to be the most Russian (ethnically, 
culturally and linguistically) one in Estonia, with 95 per cent of residents declaring Russian nationality and only 45 per cent of them being Estonian citizens [31]. The local population demanded autonomy in the early 1990s [9, p. 923]. Estonia, on the other hand, was of the opinion that the re-established boundary shall follow its pre-war location and claimed Ivangorod - with its 10000 almost exclusively Russian dwellers - to be returned. On the other hand, in intensive de-Sovietisation, de-Russification and re-Estonisation campaigns were initiated.

At the same time the process of boundarisation continued and was visible in infrastructural, social and economic disconnection of the towns, cumulating in 2004 and 2007 when the boundary dividing the towns became the EU and Schengen external border with all its consequences for it permeability.

Symbolic policies in Narva can be interpreted by the example of three monuments: «the Russian Memorial», «the Swedish Lion» and «the Lenin Statue».

The Russian Memorial and the Swedish Lion directly recall a battle from 1700, when Swedish forces defeated attacking Russian troops at the beginning of the Great Northern War. In 1900, 200 years later, the Russian Memorial was erected in the northern outskirts of the town, to commemorate the death of Russian soldiers, in the form of a cross with an inscription stressing their heroism. This could be seen as a part of the Russification policy that was intensified at that time within the Russian Empire. In 1936, in already independent Estonia a monument commemorating Swedish victory was erected and unveiled during the visit of the Swedish Crown Prince. However, it was destroyed during the WWII by Soviet bombing [43, p. 286]. In 2000, the monument called the Swedish Lion (compare the status of the «Finnish Lion» in Vyborg) was reconstructed with the financial assistance of the Swedish Institute, the political support of the central and local authorities [43] and the presence of the Swedish Minister for Foreign Affairs to commemorate the $300^{\text {th }}$ anniversary of the Swedish victory. It was placed in the historical location on the Narva riverbank, close to the neighbouring Ivangorod. The monument's re-erection was a part of the reconstruction of the old town, but it also served as a symbolic element of the reEstonianisation of the town. Identification with Sweden, the «Swedish period», in the town's history represented a symbolic return to the Estonian identity of the towns which was missing both physically and symbolically in other forms there. The Swedish legacy stressed and embodied also Estonian participation in a wider tradition - Scandinavian Europe. Consequently, it proved re-Europeanisation of the town.

At the same time, the de-Sovietisation process was conducted by removing Lenin's monument from the centrally located Peetr Square to the castle yard in 1993 [23, p. 554-556]. Inspired by the central authorities, it met with opposition and protests from the local population and was described as the «last Lenin statue in former Baltics». In 2010 an official appeal from Ivangorod was announced to transfer Lenin's monument from Narva. A part of this policy was also the dismantling of the Estland Labour Commune in 2008 (the decision was taken by the town's authorities and based on the citizens initiative -600 signatures - and resulted in removal of the remains to the local museum) and similar debates on the Viljandi Communist Regiment monument (a stone commemorating communists fighting in the War of 
Heino Nyyssönen, Jarosław Jańczak

ISSN 2078-4333. Вісник Львівського університету. Серія міжнародні відносини. 2016. Випуск 38 115

Independence), both in Narva. At the same time, however, cemeteries of the Soviet soldiers were renovated in both towns.

An important role is played by the fortresses in Narva and Ivangorod as they are considered to be both monuments and border symbols of the long-lasting history of both towns and reveal not only historical hostility but also contemporary collaboration in creating a common tourism development strategy. The fortress in Ivangorod was a Russian response to the Teutonic and later Swedish castle on the western side. Even today, both remain however areminder of a conflictive past, embodying physically a border post between the West and Russia, facing each other and guarding the border river, Narva.

\subsection{Imatra-Svetogorsk}

The border crossing between Imatra, ca. 28 100, and Svetogorskca. 16000 inhabitants, is one of several crossing points between Finland and Russia. As a twin city, we may consider Imatra-Svetogorsk as a divided city, as Finland lost the area, Enso, now Svetogorsk, to the Soviet Union in 1940 and 1944. A strictly closed border gradually opened from 1972, when the Finnish-Soviet joint company Finnstroi started reconstruction of the Svetogorsk paper mill. From 1990 onwards a kind of particular cross bordering was turned into a normal passport and visa practice, and the border was opened for tourism as well. Since 1998 the paper factory has been owned by US Paper Industrial.

The Imatra-Svetogorsk border gained even some international publicity in the 1970s, when British writer Desmond Bagley made Svetogorsk one of the scenes in his bestseller The Tightrope Men [7]. Beside action and adventure the book shed broadly light on Finnish foreign relations and the geopolitical situation. There is, for example, an episode when British intelligence cross the border among Finnish employees in order to find secret documents left there in 1944. In the novel the British were watching the chimneys of Svetogorsk from Imatra's Valtionhotelli, saying that Finns call them Stalin's finger (sic!) - according to the book Stalin had his finger on Enso, which therefore needed a twist, when the new border line was drawn on the map in 1940. According to current Foreign Minister Väinö Tanner, Enso became the first disagreement of the Moscow Peace Treaty: the new border cut Enso on the map, but Russians demanded the Enso-Gutzeit paper mill for themselves [47, p. 415].

Contrary to Narva-Ivangorod, Imatra-Svetogorsk does not have any particular medieval history - Imatra referred first to a chute, the biggest in Finland. As Sweden had lost parts of Eastern Finland to Russia twice in the eighteenth century, the Imatra region has a longer Russian "tradition" than the vast majority of Finland. Nowadays, this can be seen, for example, in the kind of eagerness to study the Russian language instead of Swedish. Because of the excellent location on the Vuoksi River, flowing from Saimaa to Ladoga, rapid industrialisation took place in the 1880s - the Imatra area on the Vuoksi River was even known as the «Finnish Ruhr». Among them was Enso-Gutzeit, a state run company since 1918 in Enso, located seven kilometers down the river from Imatrankoski. In 1948 three of these conurbations, Tainionkoski, Imatrankoski and Vuoksenniska, were united as the Borough of Imatra. 
As both Imatra and Svetogorsk both the paper industry as their common denominator, they are both somehow «ahistorical» and do not have that many historical monuments. In Imatra they took an inventory of city memorials in 2011, among them graveyards and public spaces: as there were three conurbations, three cemeteries were also established for those killed in action in the Winter and Continuation Wars. All these had received a monument in the 1960s, whilst those who faced a violent death in the German aircraft unit Kuhlmey, which assisted the Finns in the battles of 1944, were only commemorated in 1994 after the collapse of the Soviet Union [34, p. 33-34]. Moreover, there are two other kinds of public memorial at graveyards that remind about violent death and to some extent are typical of many other Finnish cities: The victims of the civil war of 1918 were commemorated: the «Reds» since the 1960s, whilst the winners, the «Whites» had unveiled their own public memorial already in 1920. Moreover, local Karelian emigrants unveiled a statue in the 1950s also in Imatra to commemorate their deceased beyond the border a type of memorial found in many communities in which Karelian refugees were relocated after the war.

When we compare Imatra's monuments to Koselleck's findings on the nineteenth century war memorials, there is one common denominator: they are all plain and simplistic, sometimes having only a stone with a memorial tablet in contrast to the romantic and eclectic style of the nineteenth century. Moreover, it is worth repeating that the public space in Imatra is kind of «ahistorical»: none of those monuments were erected before the independence i.e. during the Russian period.

The impression of «ahistorical» is even more visible in Svetogorsk, ca. 16000 inhabitants, with its public space and Soviet style architecture - one Imatra statue does not change the whole image of a «Phantom border». Located as a peripheral, remote outpost of the Soviet border zone, with inhabitants from other regions of the Soviet Union, Karelia was Russificated after WWII and new names, even new heroes, were given to many geographical sites, including new street names and the name Svetogorsk (1949) itself. However, in a broader sense we can discuss not only about twin towns, even sister cities, but a kind of twin region, including Vyborg, which had huge potential for Finland before WWII. It is worth noticing that nowadays Viipurinportti (The Gate of Vyborg) exists as a gas station complex in Lappeenranta in Finland.

Between Imatra and Vyborg Russian border control points can be found, as Soviet public monuments that remind about the struggles in the region in WWII. As a whole, Karelia has a lot of public memorials, most of them commemorating the Red Army, sometimes even with a cannon or a tank. Thus, also in Svegorsk, there is a monument to commemorate the Great Patriotic War and rituals of the former Soviet tradition of Victory Day takes place there as well. Finns, however, have their day on 27 April, referring to the end of WWII i.e. the Lapland War. As Russians define the Great Patriotic War from 1941 to 1945 - which in Finland has a different name i.e. Continuation War, these elements of "otherness" hardly can be a unifying tradition, despite flourishing foreign relations and understanding about the human losses on both sides. 
However, there are also sites for the Finnish legacy, which either survived during the Soviet era or were established and reconstructed after 1990. Volunteers have retrieved cemeteries, like the one in Svetogorsk, based on an agreement signed during Boris Yeltsin's visit in 1992 concerning cemeteries of Finnish soldiers killed in action. Despite positive and encouraging experiences with locals, also some vandalism has occurred since the end of the 1990s [16, p. 85-91].

In general, Imatra-Svegorsk looks more to the future: recent twin-city projects have dealt with more practical and cultural topics of everyday life. Despite «obstacles» like visas, different alphabets and the EU border since 1995, schools cooperate, cultural events take place twice a year at the Vuoksi Gala, unofficial contacts have a place and even encourage cycling between the cities is an issue. However, when we understand landscape and architecture as a kind of public symbolic monument as well, there is still something that historically connects both cities. First and foremost it is the Vuoksi River, whose wild and unique beauty was witnessed by the Russian Empress Catherine in 1772 and Brazilian Emperor Pedro in 1876. Imatrankoski is considered to be the oldest tourist site in Finland, including Valtionhotelli, dating back to 1902, and is a scene in Bagley's novel, too. Labelled as a model for a potential Disney Castle in the book, the hotel has served prominent travellers from Russia and other countries and is a main tourist attraction in the region.

\subsection{Kirkenes-Nickel}

Similar to Svetogorsk (Enso), also Nickel (Kolosjoki) was a part of Finland until 1944. However, the whole history of this arctic region and its ownership is more complicated. Pechenga, Petšenga in Russian and Petsamo in Finnish, remained on the Russian side, when the border was defined between Sweden and Russia in 1826. In the 1860s the Russian Czar Aleksander III basically promised the area to Finland in exchange for a small industrial region next to the Siestar River in the neighbourhood of Saint Petersburg [51]. If Stalin did have this in mind in 1939, at least there was a potential historical model for negotiations in regard to territorial changes, which however, is not stressed in the research literature.

Basically the meaning of borders in Pechenga became more important only after Finland declared its independence in 1917 - Pechenga meant an open route to the Arctic Sea in Liinahamari. Even the present main road, the E4, in Lapland, completed in 1931, was originally a road from Rovaniemi to Liinahamari and known as Jäämerentie. Finns had requested the area first from Germany and then from Britain, and made two, de facto failed, attempts to occupy the territory [51, p. 16-17]. In the Tartu Peace Treaty, which defined the eastern border in 1920, Finns gained the region, the «left arm of Maiden of Finland». For Finns, the Pechenga territory finally had a priority in the Tartu negotiations, although some were eager to annex the Eastern Karelia, too [22, p. 72-73].

Thus, until the end of the 1930s the region was significant in geopolitics and an object of great power interest: nickel, a rich ore, was found, and a British-Canadian company started mining operations in Kolosjoki. However, the ore was of interest to the Germans, too, as nickel is significant for military purposes and strengthening steel. At its peak during WWII about half of Germany's nickel was mined there. The Red 
Army occupied Pechenga and Liinahamari in the Winter War, but the region changed its owner only after the second war, the Continuation War, had ended in 1944. During the Cold War the border belonged to strictly controlled NATO-Warsaw Pact borders, in which two antagonist blocks stood against each other.

Thus, the city of Nickel (1945), ca. 13100 inhabitants, was built in 1937 as the Kolosjoki mining community, with a city plan, modern blocks of flats and even a cinema. In this sense it has similarities with Norwegian Kirkenes, which is also a city of mining and refinement. In 1944 retreating Germans destroyed the city, and the Soviets rebuilt it. Later a monument, an obelisk, emerged on the market square to commemorate the throwing out of the Germans from Pechenga in 1944 [51, p. 553]. However, here we may say that the meaning of the monument was negotiated by the new power: the pillar was basically the same, which Finnish authorities had erected in 1938 on a site where the Finns had first raised a Finnish flag in 1920 [48, p. 419].Thus, at first the pillar symbolized independence and the annexation of Pechenga to Finland, which was an at the time current confrontation with Bolshevist forces in the area.

Compared to the Imatra-Svetogorsk case, this is more a top-down integration laboratory of twinning. Pertti Joenniemi sees the present cooperation between Nickel and Kirkenes as a kind of local foreign policy: the initiative did not emerge with the cities themselves but was first and foremost coined by the Norwegian and Russian foreign ministers and testified not only to changes in the nature of the two states themselves and their approach to borders and bordering but also to a new way of conducting foreign policy; with both Kirkenes and Nickel being encouraged to join in through their twinning [19, p. 1].

Nickel's sister city Kirkenes (Kirkkoniemi in Finnish) means church headland, and is a town of ca. 3500 inhabitants. Thus, the Norwegian Kirkenes, the smallest of our cases, is also the only city which is smaller than its Russian counterpart. Its WWII legacy is somehow extraordinary as the region was one of the most bombed areas in the whole of Europe. As Norway was occupied during WWII, Kirkenes served as the main base for supplies to the Murmansk front. However, also much resistance against the occupation occurred, with some cooperation by the Norwegian partisans with the Soviet forces. There is a monument next to the city for those 11 freedom fighters, who helped the partisans to collect information about the occupation and were therefore killed.

Although the fighting amounted to an almost full dismantling of the dwellings and caused profound destruction, the image of the Soviet forces has remained rather positive as is indicated among other things by a statue devoted to Soviet soldiers [19, p. 14]. Thus, there is a particular Russian, quite traditional, memorial standing on a hill-top in the city centre: that of a soldier depicted with a gun settled and on high ground. The monument was installed in 1952 as a tribute to the Red Army's sacrifice during the Pechenga-Kirkenes offensive between 15 and 25 October 1944, when parts of Finnmark County in north-eastern Norway were liberated from Nazi occupation [26]. The text on the monument says, «In memory of the brave Soviet soldiers that liberated Kirkenes in 1944» - the monument was supposed by the end of the Cold 
Heino Nyyssönen, Jarosław Jańczak

ISSN 2078-4333. Вісник Львівського університету. Серія міжнародні відносини. 2016. Випуск 38 119

War to be the only one of its kind in a NATO country [26]. Being a local initiative, the monument was disregarded in Oslo in the era of the East-West confrontation. Together with the geopolitical change in Europe after 1989 and regional collaboration between Norway and Russia in the arctic region, it was however employed by the central authorities of both states as a symbol of friendly relations. It is based on historical legacies and mutual respect, revealed by a positive attitude towards the Soviet liberators, which is exceptional in the western neighbours of Russia.

In general, the monument serves two kinds of rituals: annual commemorations on the one hand and high level meetings on the other. For example, after finishing the Barents Summit in 2013 both the Russian and Norwegian prime ministers visited the Russe monumentet. Prime Minister Medvedev laid down a large wreath with a bow saying, «From the Russian Government» before being followed by the current Secretary General of NATO Jens Stoltenberg, the Prime Minister of Norway at that time. Earlier for example, the Russian accounting chamber chairman and his Norwegian counterpart had laid flowers at the Russian soldier monument during their visit in Kirkenes. Secondly, by this monument, both Russians and Norwegians in Kirkenes celebrate both the Norwegian Liberation Day on 8 May and the Russian Victory Day on 9 May to symbolise the liberation of the town on 25 October [32; 45; 49]. It is notable that this commemoration has taken place together: children and town officials have joined the local Russia consul, or like in the October anniversary, veterans from both countries. Particularly for the Russians, this is a political gesture of good will at a time when East European peoples try to forget the whole role of the Red Army in WWII.

Moreover, in Kirkenes there is still one monument, which is connected to WWII, and which was unveiled much later on the 50th anniversary in 1994. In the centre square 'the mother's monument', a woman holding a child in her arms, is a tribute to the women of Kirkenes during the war. At the background to this, there was the idea that the women of Kirkenes deserved recognition for keeping the kids fed, alive and comforted during a three-year period when the air raid sirens were going off on an almost daily basis. In 2011, when one of the authors of this paper visited the city, the statue had absorbed a new meaning. As Anders Breivik had just murdered 77 innocent people, people commemorated the attack by bringing candles and flowers to this statue.

\section{Interpretation}

The three investigated couples reveal a lot about the nature of the boundary between the «Scandinavian space» and Russia. Being laboratories of interstate relations they are a location of very intensive symbolic policies, which are visible in public space monuments. At the same time they reveal Scandinavian diversity in regard to organizing relations with the Eastern neighbour. Estonia is using its Scandinavian legacy in Narva to cut itself off from Russia and prove its Nordic and European identity. Finland cooperates with Russia with a relatively low profile as a part of its pragmatism and political realism. And Norway uses the Soviet soldiers monument in Kirkenes as proof of peaceful and constructive collaboration with its Eastern neighbour. 
As Siobhan Kattago stresses, «the war memorials dotted along the Narva River between Estonia and Russia are testament to the different layers of Estonian history: Swedish, Tsarist Russian, Estonian Republic, Nazi and Soviet occupations» [25, p. 431]. The monuments show how the towns, in a down-scaled perspective, reflect state relations between Estonia and Russia [20, p. 286]. The separation of Narva from Ivangorod after 1991 illustrates the separation of Estonia from Russia and symbolically express the Estonian and European project in the East [23, p. 549] as well as both local and Estonian belonging to both the European and Scandinavian legacy. The removal of Lenin's monument symbolizes the breaking with the Soviet legacy (as it was so dependent on Russia in the twentieth century). The Swedish Lion's recreation not only brakes more generally ties with Russia (looking back to the beginning of the seventeenth century) but also stresses links with Sweden, Scandinavia and Europe. Additionally, the political discourse of the local authorities in regard to «the Swedish Lion» recalled the «Happy Swedish Time», which was characterised in the re-invented collective memory by freedom (historically given to the peasantry), peace and economic prosperity [43, p. 286].

Basically different time periods can be seen in Imatra-Svetogorsk and NickelKirkenes, too. However, these cases and their monuments are more «ahistorical» and stress recent history. Located basically on the periphery, the sparsely populated North belonged to joint governance until the early nineteenth century. It is also notable that monuments in Imatra usually refer to the post-1917 period. Nevertheless, the WWII is very significant in both cases and annually commemorated. Imatra does not differ from many other cities in Finland - except that there are three cemeteries with monuments due to the three communities before 1948. It is notable that two of these monuments represent a more modernist, abstract style, whilst the other has a more traditional view of a woman figure. Moreover, it is notable that all memorials have the years 1939-1945 carved in the stone, thus the Winter War, the Continuation War and the Lapland War are all included.

In contrast to Finland, a co-belligerent of Nazi-Germany from 1941-1944, the anti-Fascist legacy is easier to find as a common denominator for cooperation in Norway and Russia, even in both twin-cities and on both sides of the border. Victory Day is commemorated in Russia, as in Kirkenes, in which these rituals can be seen as a tribute to a historical fact on the one hand, i.e. the Red Army liberated Kirkenes but also left Norway for good. Thus, on the other hand, the commemoration offers a frame for local foreign policy, a kind of laboratory, which was encouraged by both political centres. This was especially the case after 1989 when new relations were to be established by both states. However, the main difference to Finnish monuments is that, like on the Svetogorsk-Vyborg road, there are only the years 1941-1945 carved on war memorials. Seemingly, WWII means different wars for different nations - for Russians it symbolises Finns and German Nazis attacking the Soviet Union from 1941 onwards - and not the 1940/1944 border, which is the basis for all present cooperation with the twin-cities on this EU-Russia border. 
Twin towns' monuments as invented traditions

\begin{tabular}{|l|l|l|l|}
\hline & \multicolumn{1}{|c|}{ Kirkenes-Nickel } & \multicolumn{1}{|c|}{$\begin{array}{c}\text { Imatra- } \\
\text { Svetogorsk }\end{array}$} & Narva-Ivangorod \\
\hline Values & $\begin{array}{l}\text { anti-Fascism } \\
\text { cooperation }\end{array}$ & cooperation & $\begin{array}{l}\text { freedom, } \\
\text { prosperity }\end{array}$ \\
\hline Legitimisation & $\begin{array}{l}\text { local foreign policy } \\
\text { new quality of regional } \\
\text { collaboration }\end{array}$ & regionalism & $\begin{array}{l}\text { (re-)Estonisation } \\
\text { de-Sovietisation }\end{array}$ \\
\hline Belonging & Arctic north & gateway & $\begin{array}{l}\text { Western world } \\
\text { symbolised by } \\
\text { Swedish legacies }\end{array}$ \\
\hline
\end{tabular}

Source: Authors' concept

Summarising the above-presented remarks, the authors can state that both the tested monuments, as well as the social practices they are involved in, invent traditions and can be interpreted as follows: the means by which (a) to transfer new values, (b) to legitimise relations of authority and institutions' status and (c) to generate a feeling of belonging. As presented in Table 1, Kirkenes' monuments by using war symbolism present - in Koselleck's understanding - the anti-fascist message and is currently reinterpreted as carrying the value of cooperation and good neighbourhood. It became a symbol of warmer relations between the centres (being influenced by the border located peripheries) as well as that of the gradual destruction of an isolating boundary with a much more cooperation-oriented frontier. In Imatrathe basic idea is to respect each other's history despite different interpretations and concentrate on the future. In Narva the dominating values are freedom and the promise of prosperity. With regard to legitimisation, the Scandinavian/Russian north stresses the new quality of local collaboration and the role of local authorities and communities in this process, where the south legitimises (re-)Estonisation de-Sovietisation. In Norway, it results in belonging to the (common and cross-border) Arctic region that undermines historical divisions and replaces the boundary with a frontier. In Estonia, it is quite the opposite: by splitting and isolating the boundarisation process, it is necessary to prove the othering process as well as belonging to the Western world and European project. Consequently, three variants of historic-political (re)interpretations have been employed in the investigated pairs. They are accordingly: new economic neighbourhood relations, EU common border and conflicting revival of Swedish historic legacy.

\section{Conclusions}

All our cases of borders and monuments are quite different: during the Cold War, Estonia and Russia basically belonged to the same union, whilst the Finnish-Soviet border in principle symbolised peaceful coexistence and cooperation between two different political systems. However, the border between Norway and the Soviet Union divided two rival military blocs. Now, the Scandinavian Russian border is 
mostly also the Eastern border of the European Union. But the relations now seem to be reversed: staring with the message of new friendly relations between former enemies on the Norwegian-Russian border, to the isolation-oriented relations between former parts of the same political entity on the Estonian-Russian border.

Rhetorically, monuments and cultural memory can be directed towards either a domestic or a universal audience. Basically, war memorials in Finland and Karelia had this domestic function - even most of Karelia was closed for Finns and others until 1990. Since the borders were opened in the 1990s more Finnish memorials exist nowadays in Karelia, some of which have been erected by support from the Finnish state. In Kirkenes the function is more universal, and there the Russian soldier can be seen as a symbol of political cooperation. This is especially so in the context of its reinterpretation after 1989 and national centres using the local border monuments. In Estonia there are signs of the politics of the past by choosing i.e. inventing an appropriate tradition. Here, also the Estonian centre is involved, but separateness is the political aim. Following Pekonen's argument [38, p. 41] the national centres «authorize these symbols» to use them for their own purposes in creating relations between states in the changing political environment.

Consequently, «Scandinavian space» when confronted with Russia, is not homogenous, and the symbolic message sent in the «laboratories» depends on the place, the historic legacies as well as the current political situation. The same refers to the separating or unifying character of this border(s).

\section{REFERENCES}

1. Adoneva Svetlana B. Kategorii nenastoiashchego vremeni: Antropologicheskie ocherki / Svetlana B. Adoneva. - Sankt-Peterburg, 2001.

2. Ankersmit Frank R. Remembering the Holocaust: Mourning and Melancholia / Frank R. Ankersmit // Historical Perspectives on Memory ; Anne Ollila (ed.). - Helsinki, 1999.

3. Assmann Jan. Das kulturelle Gedächtnis. Schrift, Erinnerung und politische Identität in frühen Hochkulturen / Jan Assmann. - München, 1992.

4. Anderson James. Theorizing State Borders: Politics, Economics and Democracy in Capitalism / James Anderson // Center for International Border Research Working Papers. - 2001.

5. Asher Andrew. Transnational Mythmaking in Post-Soviet Europe: Cold War and EU Monuments in a Polish - German «Divided City» / Andrew Asher and Jarosław Jańczak // Art and Politics: Case-Studies from Eastern Europe ; Linara Dovydaityte (ed.). - Kaunas, 2007.

6. Assmann Jan. Religion and Cultural Memory / Jan Assmann. - Stanford, 2006.

7. Bagley Desmond. The Tightrope Men / Desmond Bagley. - London, 1973.

8. Browning Christopher S. Geostrategies of the European Neighbourhood Policy / Christopher S. Browning and Joenniemi Pertti // European Journal of International Relations. - 2008.

9. Burch Stuart. Empty Spaces and the Value of Symbols: Estonia's 'War Monuments' from Another Angle / Stuart Burch and David J. Smith // Europe-Asia Studies. - 2007.

10. Buursink Jan. The binational reality of border-crossing cities / Jan Buursink // GeoJournal. 2001.

11. Ehlers Nicole. Introduction. Binational cities and their regions: From diverging cases to a common research agenda / Nicole Ehlers, Jan Buursink, Frans Boekema // GeoJournal. - 2001.

12. Evans Graham. The Penguin Dictionary of International Relations / Graham Evans and Newnham Jeffrey. - London, 1998.

13. Gasparini Alberto. European Border Towns as Laboratories of Differentiated Integration / Alberto Gasparini // ISIG Quarterly of International Sociolog. - 1999-2000. 
14. Hedetoft Ulf. On Nationalisers and Europeanisers in Contemporary Europe / Ulf Hedetoft // Political Symbols, Symbolic Politics. European identities in transformation ; Ulf Hedetoft (ed.). Aldershot, 1998.

15. Hobsbawn Eric. Terrance Ranger / Eric Hobsbawn // The Inventions of Tradition. - Cambridge, 1983.

16. Hämäläinen-Abdessamad Maija. Yhteisvastuupyhistämaista / Maija Hämäläinen-Abdessamad // Vuoksenvarrellavieretysten. Imatra ja Svetogorskyhteistyössä ; Milla Hannula (ed.). - Lappeenranta, 2007.

17. Jańczak Jarosław. Unia Europejska i jej granice. W poszukiwaniu modelu integracji na europejskich peryferiach / Jarosław Jańczak // Przegląd Politologiczny. - 2010.

18. Jańczak Jarostaw. Border Twin Towns in Europe. Cross-border Cooperation at a Local Level / Jarosław Jańczak. - Berlin, 2013.

19. Joenniemi Pertti. City-twinning as Local Foreign Policy: The Case of Kirkenes-Nickel / Pertti Joenniemi // CEURUS EU-Russia Paper. - 2014.

20. Joenniemi Pertti. When two aspire to become one: City-twinning in Northern Europe / Pertti Joenniemi and Alexander Sergunin // Journal of Borderland Studies. - 2011

21. Joenniemi Pertti. When two aspire to become one: City-twinning in Northern Europe / Pertti Joenniemi and Alexander Sergunin // DIIS Working Paper. - 2009.

22. Kaarninen Pekka. PetsamonliittäminenSuomeen / Pekka Kaarninen // Turjanmerenmaa. Petsamonhistoria 1920-1944 ; JoukoVahtola, SampsaOnnela (eds.). - Rovaniemi, 1999.

23. Kaiser Robert. The performativity of scale: the social construction of scale effects in Narva, Estonia / Robert Kaiser and Elena Nikiforova // Environment and Planning D: Society and Space. - 2008.

24. Jukka Kanerva. Transformation of Ideas on a Periphery / Jukka Kanerva and Palonen Kari. Helsinki, 1987.

25. Kattago Siobhan. Commemorating Liberation and occupation: War Memorials Along the Road to Narva / Siobhan Kattago // Journal of Baltic Studies. - 2008.

26. Kirkenes commemorated liberation day [Electronic resource] // Barents Observer. - 25 October 2011. - Mode of access : barentsobserver.com.

27. Koselleck Reinhart The practice of Conceptual History. Timing History, Spacing Concepts / Koselleck, Reinhart. - Stanford, 2002.

28. Kristof Ladis K. D. The Nature of Frontiers and Boundaries / Ladis K. D. Kristof // Annals of the Association of American Geographers. - 1959.

29. Lebow Richard Ned. The Future of Memory / Richard Ned Lebow // Annals of the American Academy of Political and Social Science. - 2008.

30. Lundén Thomas. European Twin Cities: models, examples and problems of formal and informal co-operation / Thomas Lundén // ISIG Quarterly of International Sociology. - 2004.

31. Lundén Thomas. Valga-Valka, Narva-Ivangorod. Estonia's Divided Border Cities Cooperation and Conflict Within and beyond the EU / Thomas Lundén // Conflict and Cooperation in Divided Cities ; Jarosław Jańczak (ed.). - Berlin, 2009.

32. Medvedev honoured Red Army liberators [Electronic resource] // Barents Observer. - 4 June 2013. - Mode of access : barentsobserver.com.

33. Morehouse Barbara J. Theoretical Approaches to Border Spaces and Identities / Barbara J. Morehouse // Challenged Borderlands. Transcending Political and Cultural Boundaries ; Vera Pavlakovich-Kochi, Barbara J. Morehouse, Doris Wastl-Walter (eds.). - Surrey, 2012.

34. Nalli Tuomas. Imatranmuistomerkit. Muistomerkkieninventointi 1.5.2011-30.7.2011 / Tuomas Nalli. - Imatra, 2011.

35. Newman David. On borders and power: A Theoretical Framework / David Newman // Journal of Borderland Studies. - 2003.

36. Nyyssönen Hein. Muisti, kokemus ja historiallinen käänne kansainvälisessä politiikassa: Näkökulmana Richard Ned Lebowja Reinhart Koselleck / Heino Nyyssönen and Halla Matti // Kosmopolis. - 2013.

37. O'Dowd Liam. Frontiers of sovereignty in the new Europe / Liam O'Dowd and Wilson Thomas // Borders of Europe ; Nail Alkan (ed.). - Bonn, 2002. 
38. Pekonen Kyösti. Symbols and Politics as Culture in the Modern Situation: the Problem and Prospects of the «New» / Kyösti Pekonen // Contemporary Political Culture. Politics in a Postmodern Age ; John R. Gibbins (ed.). - London, 1989.

39. Phantomgrenzen in Ost Mittel Europa [Electronic resource]. - Mode of access : www.phantomgrenzen.eu.

40. Pihlak Marje. Estonian Country Report / Marje Pihlak // Monitoring European Border-crossing points on the EU's Eastern Border: Estonian and Russian Case Studies ; Heiko Pääbo, Marje Pihlak (eds.). - Tartu, 2008.

41. Schultz Helga. Twin Towns on the Border asLaboratories of European Integration / Helga Schultz, Katarzyna Stokłosa, Dagmara Jajeśniak-Quast // FIT Discussion Paper. - 2002.

42. Scott James. Mapping Conceptual Change in Thinking European Borders / James Scott // Conference Bergamo. - Italy, 3-5.07.2013.

43. Smith David J. You've got to know history! Remembering and Forgetting the past in the present day Baltic / David J. Smith // Forgotten Pages in Baltic History: Diversity and Inclusion ; Martyn Housden, David J. Smith (eds.). - Amsterdam and New York, 2011.

44. Sprengel Bolesław. Pogranicze a polityka bezpieczeństwa / Bolesław Sprengel // Pogranicze. Polish Borderland Studies. - 2013.

45. Stepashin and Kosmo laid wreath at Russian soldier monument [Electronic resource] // Barents Observer. - 14 April 2010. - Mode of access : barentsobserver.com.

46. Szalbot Magdalena. Społeczno-kulturowa specyfika przygranicznych miast podwójnych Europy jako problem badawczy / Magdalena Szalbot // Studia etnologiczne i antropologiczne. Etnologia na granic ; Irena Bukowska-Floreńska, Grzegorz Odoja (eds.). - Katowice, 2011.

47. Tanner Väinö. Olin ulkoministerinä talvisodan aikana / Väinö Tanner. - Helsinki, 1950.

48. Vahtola Jouko. Turjanmeren maa. Petsamonhistoria 1920-1944 / Jouko Vahtola and Onnela Sampsa. - Rovaniemi, 1999.

49. Victory day celebration [Electronic resource] // Barents Observer, 9 May 2011. - Mode of access : barentsobserver.com.

50. Timothy Dallen J. Political boundaries and tourism: borders as tourist attractions / Dallen J. Timothy // Tourism Management. - 1995.

51. Uola Mikko. Petsamo 1939-1944 / Mikko Uola. - Helsinki, 2012.

52. Vainonen Joel M. Monrepos'n särjetty leijona / Joel M. Vainonen // Etelä-Suomen Sanomat. 8 September 2013.

53. Walters William. The Frontiers of the European Union: A Geostrategic Perspective / William Walters // Geopolitics. - 2004.

54. Vares Mari. Geography and Nation - Scientific Representations of «The Space of Nation» in Finland and in Hungary, 1917-1945 / Mari Vares // Nations and Their Others - Finland and Hungary in Comparison ; Heino Nyyssönen and Mari Vares (eds.) - Helsinki, 2012. 
Heino Nyyssönen, Jarosław Jańczak

ISSN 2078-4333. Вісник Львівського університету. Серія міжнародні відносини. 2016. Випуск 38

\title{
КОНФЛІКТ І СПІВПРАЦЯ В ГРОМАДСЬКОМУ ПРОСТОРІ. СИМВОЛІЧНЕ ПОГОДЖЕННЯ ІСТОРИЧНОГО І СУЧАСНОГО СКАНДИНАВСЬКО-РОСІЙСЬКОГО КОРДОНУ
}

\author{
Хейно Нююсьонен \\ Університет м. Тампере, \\ вул. Калевантіє, 4, м. Тампере, Фінляндія, 33100, тел. (+358 3) 355 111, \\ e-mail:nyyssonen.heino@gmail.com
}

Ярослав Янчак

Університет в Познані імені Адама Міџкевича, вул. Умультовська, 89а, м. Познань, Польща, 61-614, тел. (+48 061) 8296625 , Свропейський університет Вядріна, вул. Грьосе Шарн,Франкфурт на Одері, Німеччина, 15230, тел.+4933555342581, e-mail: jaroslaw.janczak@aтu.edu.pl

\begin{abstract}
Прикордонні міста-побратими є такими місцями, що мають неабияку символічність для ключових проектів, що мають на меті створення пам'ятних місць національного і міжнародного значення. Місцеві та центральна влада використовують пам'ятники та інші символи як спосіб «створювати традиції» [15], та розповідати про колись існуючі конфлікт, співробітництво і навіть партнерство. Метафора «Лабораторія інтеграції» [13] робить їх ідеальним місцем для транскордонного діалогу. Посилаючись також на твердження Рейнхарта Козеллека [27] стосовно військових меморіалів ми стверджуємо, що пам'ятники представляють символи виставлені в громадських місцях: вони мають певну функцію, виражаючи певні ідеї, «які не $\epsilon$ матеріальними або які не можна одразу осягнути» [38, с. 40]. Більше того, символ «розповідає про іншу реальність і є кристалізацією лінгвістичного опису» [38, с. 40]. Таким чином «матеріальні об'єкти часто втілюють та презентують абстрактні ідеї, такі як недружні відносини, міжнародний соціалізм або євроінтеграцію, а також посилення сприйняття цих ідей населенням» [5, с. 204]. Метою цієї статті є дослідити історіографічно символіку громадських місць, саме пам'ятники, пам'ятки культури і політики в трьох прикордонних містах-побратимах (Нарва-Івангород, ІматраСвятогірськ і Кіркенес-Нікель). Основна увага буде приділена західній частині кордону. На основі цих прикладів в статті висвітлюються ширші зовнішньополітичні орієнтації, зокрема, ті, які існували після Другої світової війни: будучи місцями інтенсивних взаємодій, вони відкривають історичну спадщину конфлікту між «скандинавським простором» та Росією. Крім того, останнім часом вони використовуються (відповідно) у трьох вимірах історико-політичної інтерпретації: нові економічні добросусідські відносини, спільного кордону ЄС і конфліктного відродження шведської історичної спадщина.
\end{abstract}

Ключові слова: Європейсько-російський кордон; граничити; розмежування; прикордонні символи. 
Heino Nyyssönen, Jarosław Jańczak

\title{
КОНФЛИКТ И СОТРУ ДНИЧЕСТВО В ОБЩЕСТВЕННОМ ПРОСТРАНСТВЕ. СИМВОЛИЧЕСКОЕ СОГЛАСОВАНИЕ ИСТОРИЧЕСКОЙ И СОВРЕМЕННОЙ СКАНДИНАВО-РОССИЙСКОЙ ГРАНИЦЫ
}

\author{
Хейно Нююсьонен \\ Университет г. Тампере, ул. Калевантие, 4, 33100 Тампере, Финляндия, тел. \\ (+358 3) 355111,e-mail: nyyssonen.heino@gmail.com \\ Ярослав Янчак \\ Университет имени Адама Мицкевича в Познани, \\ ул. Умультовская, 89а, Познань, Польша, 61-614, тел. (+48 061) 8296625 , \\ Европейский университет Вядрина, \\ ул. Грьосе Шарни, Франкфурт-на-Одере, Германия, 15230, \\ тел. +4933555342581, e-mail: jaroslaw.janczak@amu.edu.pl
}

\begin{abstract}
Пограничные города-побратимы являются местами, которые имеют большую символичность для ключевых проектов, имеющих целью создание памятных мест национального и международного значения. Местные и центральные власти используют памятники и другие символы как способ «создавать традиции» [15], и рассказывать о некогда существующих конфликтах, сотрудничестве и даже партнерстве. Метафора «Лаборатория интеграции» [13] делает их идеальным местом для трансграничного диалога. Ссылаясь также на утверждение Рейнхарта Козеллека [27] относительно военных мемориалов, мы утверждаем, что памятники представляют символы, которые выставлены в общественных местах: они имеют определенную функцию, выражая определенные идеи, «которые не являются материальными или которые нельзя сразу понять» [38, с. 40]. Более того, символ «рассказывает о другой реальности и является кристаллизацией лингвистического описания» [38, с. 40]. Таким образом «материальные объекты часто воплощают и представляют абстрактные идеи, такие как недружественные отношения, международный социализм или евроинтеграцию, а также усиление восприятия этих идей населением» [5, с. 204]. Целью этой статьи является исследовать историографически символику общественных мест, а именно памятники, памятники культуры и политики в трех приграничных городах-побратимах (Нарва-Ивангород, Иматра-Светогорск и Киркенес-Никель). Основное внимание будет уделено западной части границы. На основе этих примеров в статье освещаются более широкие внешнеполитические ориентации, в частности, те, которые существовали после Второй мировой войны: будучи местами интенсивных взаимодействий, они открывают историческое наследие конфликта между «скандинавским пространством» и Россией. Кроме того, в последнее время они используются (соответственно) в трех измерениях историко-политической интерпретации: новые экономические добрососедские отношения, общей границы ЕС и конфликтного возрождения шведского исторического наследие.
\end{abstract}

Ключевые слова: Европейско-российская граница; граничить; разграничение; пограничные знаки. 